\section{Bones, stones and Buckland}

\section{Roy Porter}

The Great Chain of History: William Buckland and the English School of Geology (1814-1849).

By Nicolaas A. Rupke. Clarendon: 1983. Pp.322. £22.50, \$45.
IN the heroes versus villains jousts which have traditionally dominated histories of English geology, the "Diluvialist" school of the early nineteenth century has always had a bad press. In contrast to the "great tradition" rising from Hutton through William Buckland, the Conybeare brothers and Daubeny have been depicted as black sheep, retrogressive and wrong. After all, in opting for neptunism rather than plutonism, diluvialism not fluvialism, and leaning towards cataclysmic rather than actualistic geomorphological agency, they backed the wrong horses. Worse, in championing catastrophism they were betraying science by grinding theological axes. William Buckland, later Dean of Westminster, pronounced that geology which did not ascend to religious truth was unsatisfactory; and in his Reliquiae Diluvianae (1823: Relics of the Deluge) argued that bone-cave evidence gave "decisive and incontrovertible" proofs of his historicity of Noah's Flood. In doing so, he committed the sin against Bacon of unwisely mingling Genesis and Geology; worse, he finally ended up with egg on his face, being forced to retract some years later in the decent obscurity of an ignominious footnote. But historians have always seen Buckland - with his giant bone-bag, scientific clowning and fascination with coprolites - as a bit of a buffoon.

In his erudite work of revisionism, Nicolaas Rupke shows that this reading of the Oxford Diluvialists is largely caricature, foisted upon them by opponents such as Lyell, and accepted uncritically ever since. Of course, there is no denying that they aimed to harmonize their fieldwork with Christian Creationism; but, Rupke asks, how else was Buckland, the first Reader in Geology, to establish the science in pre-Reform Oxford, still exclusively Anglican and dominated by the clergy? The new science had to be grafted upon old scholasticism, the Book of Nature reconciled with both Scripture and written historical records. In any case, the religion of Buckland and his friends was not dogmatic but liberal, sweet reason itself compared to the obscurantist Evangelicals and Tractarians who sniped at the emergent science. Nor did their theology blinker their science; it rather suggested valuable geological perspectives, such as a search for origins, and an eye for the adaptation of organism and environment. Such outlooks stimulated them to plot the Lyell and beyond, geologists such as sequence of the strata, and reconstruct extinct flora and fauna using comparative anatomy; on this basis they made valuable contributions towards recovering the ecology of lost worlds and understanding the laws of geological change.

Orientated thus, Buckland's Oxford School formed the headwaters of what was to become mainstream Victorian historical geology. Even their soft spot for cataclysmic agency could prove fruitful. It was no accident that Buckland, one-time prime devotee of the Deluge, became Britain's first and foremost convert to Agassiz's glacialism and theory of Ice Ages. In view of all this, Rupke argues, we need to view the dynamics of geology not as a series of encounters in which truth vanquished error, but as the conflux of many different schools, each contributing its own insights; amongst these, this "English School" takes its place alongside the Scottish (Huttonian), the German (Wernerian) and the French (Cuvierian).

Rupke's rehabilitation is generally persuasive, though certain doubts remain. For one thing, he himself occasionally counters caricature with caricature. In rescuing Buckland from Lyell's tarbrush, he has sketched a one-sided portrait of Lyell, oversimplifying him into an " $a$ priori" and "doctrinaire" Uniformitarian. Then take his contention that the essence of Oxford geology lay not in religious catastrophism but in its commitment to historical geology. It is an important corrective. But it skims somewhat over two facts. First, before the 1830s, English geology was probably more orientated towards descrip- tive stratigraphy than to reconstructing Earth history. Second, Buckland and his followers did indeed believe that science proved the crust had undergone stupendous convulsions (the term "catastrophism" was coined after all by their sympathizer, William Whewell). Right to the end of his career, Buckland felt confident that science pointed to divine interventions (it was the "clear design of Providence", he thought, by strategic placement of mineral resources, to make Britain "the most powerful and richest nation on earth"'). Indeed, it was Buckland who had been largely responsible for making the Deluge a respectable topic of scientific inquiry.

Before Buckland, the elite of British geology had been keeping judiciously silent about Noah's Flood. By contrast Buckland's rash confidence opened a Pandora's Box, whose outcome was the protracted sterile controversy about natural law and divine miracles which dogged English (but not Continental) natural history for the next generation. This is one reason why we must be wary of Rupke's tendency to conflate Oxford geology with English geology. There were numerous other types of contemporary researchers including surveyors such as William Smith, and the Geological Society of London elite, and most of these viewed geology in a more secular light.

Rupke has cleverly crafted his book as a historical nest of three boxes: a broad conspectus on English geology, which contains a close-up of the Oxford School, enclosing finally a portrait of Buckland. His view of Buckland as the key to English geology in the generation before Lyell is just, and makes one hope he will one day give us a biography of this engaging and misunderstood pioneer.

Roy Porter is at the Wellcome Institute for the History of Medicine, London, and is author of The Making of Geology (Cambridge University Press, 1977).
The savants eat out — dinner in the model of Iguanodon at the Crystal Palace, near Croydon in south London, on 31 December 1853. 